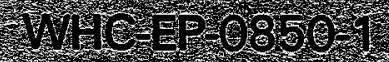

\section{Hanford Facility \\ Resource Conservation PE EEIVE and Recovery Act Permit General Inspection Plan}

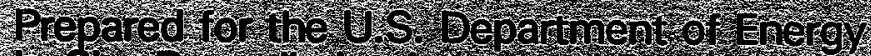

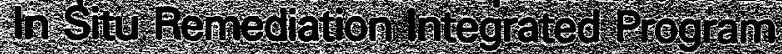

(1)

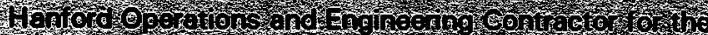

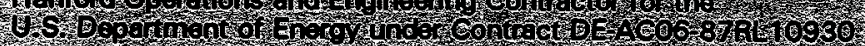

A poroved for Public Rele ase 


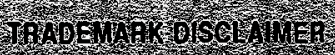

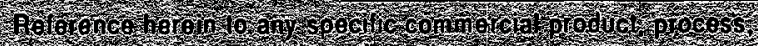

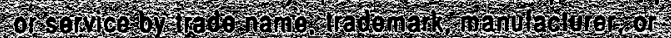

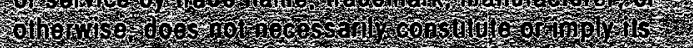

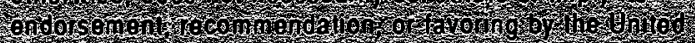

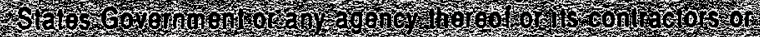
Sil bovintactors

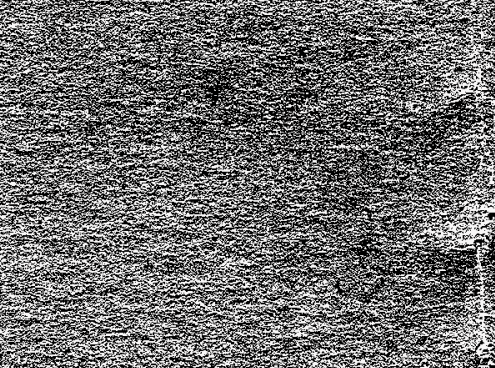

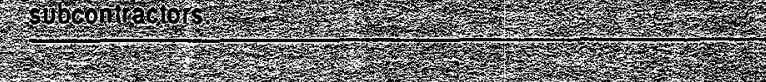

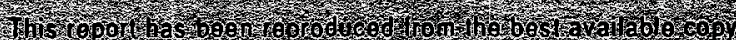

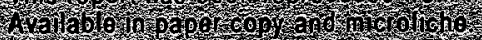

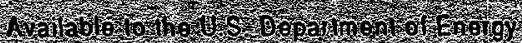

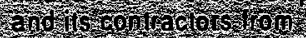

O.

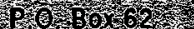

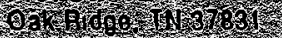

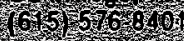

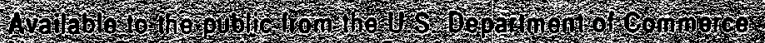

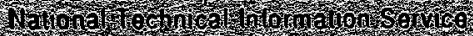

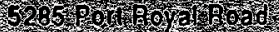

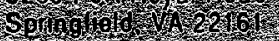

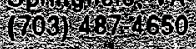

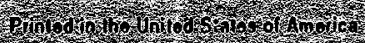

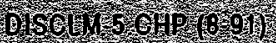




\title{
Hanford Facility Resource Conservation and Recovery Act Permit General Inspection Plan
}

\author{
D. B. Beagles
}

Date Published

December 1995

\author{
DISCLAIMER
}

This report was prepared as an account of work sponsored by an agency of the United States . Government. Neither the United States Government nor assumes any legal liability or responsiemployees, makes any warranty, express or impled, of any information, apparatus, product, or bility for the accuracy, completeness, or usefulness of any information, apparatys, prots. Referprocess disclosed, or represents that its use would not infringe privately trade name, trademark, ence herein to any specific commercial product, process, or service by thade ndorsement, recommanufacturer, or otherwise does not necessarily constitute or imply its endereof. The views mendation, or favoring by the United States Government or any age or reflect those of the and opinions of authors expressed herein do not

United States Government or any agency thereof.

Prepared for the U.S. Department of Energy
In Situ Remediation Integrated Program

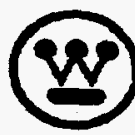

Westinghouse Hanford Company

P.O Box 1970

Richland, Washington

Hanford Operations and Engineering Contractor for the

U.S. Department of Energy under Contract DE-AC06-87RL10930

\section{MASTER}




\section{RELEASE AUTHORIZATION}

Document Number: WHC-EP-0850-1

Document Title: Hanford Facility Resource Conservation and Recovery Act Permit General Inspection Plan

Release Date: $\quad 12 / 20 / 95$

This document was reviewed following the procedures described in WHC-CM-3-4 and is:

APPROVED FOR PUBLIC RELEASE

WHC Information Release Administration Specialist:

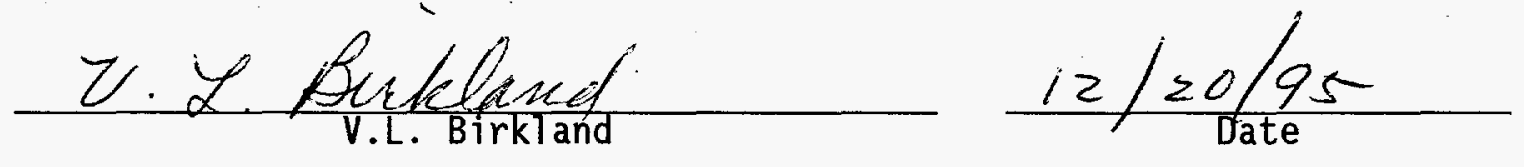


WHC-EP-0850-1

\section{CONTENTS}

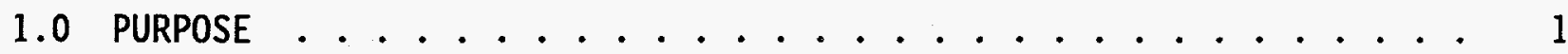

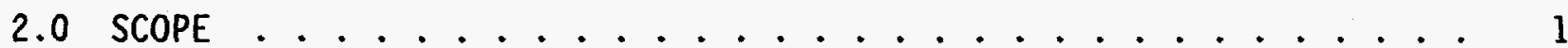

3.0 DEFINITIONS . . . . . . . . . . . . . . . . . . . . . 1

4.0 REQUIREMENTS . . . . . . . . . . . . . . . . . . . . . . 1

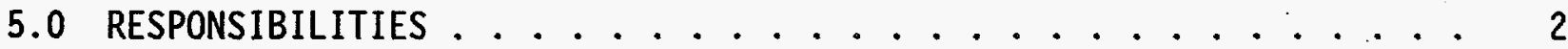

5.1 RCRA Field Services . . . . . . . . . . . . . . . 2

5.2 RO . . . . . . . . . . . . . . . . . . 2

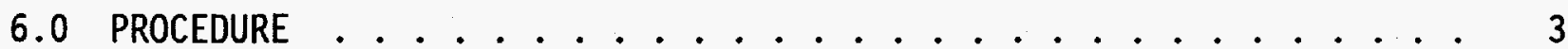

6.1 INSPECTION CRITERIA

6.2 FREQUENCY ....................... 3

6.3 INSPECTIONS . . . . . . . . . . . . . . . . . . . . . 4

6.4 REMEDIAL ACTIONS ..................... . . . 5

6.5 INSPECTION REPORT ..................... 5

6.6 RECORDS . . . . . . . . . . . . . . . 5

\section{TERMS}

Ecology

RCRA

RFS

$\mathrm{RL}$

RO

TSD

WAC
Washington State Department of Ecology

Resource Conservation and Recovery Act of 1976

RCRA Field Service

U.S. Department of Energy, Richland Operations Office Responsible Organization

Treatment, Storage, and Disposal

Washington Administrative Code 
WHC-EP-0850-1

This page intentionally left blank. 


\section{HANFORD FACILITY RESOURCE CONSERVATION AND RECOVERY ACT PERMIT GENERAL INSPECTION PLAN}

\subsection{PURPOSE}

This inspection plan describes the activities that shall be conducted for a general inspection of the Hanford Facility.

\subsection{SCOPE}

The Hanford Facility Resource Conservation and Recovery Act (RCRA) Permit, Part II.0 General Inspection Requirements, includes a requirement that general facility inspections be conducted of the 100, 200 East, 200 West, 300, 400, and 1100 Areas and the banks of the Columbia River. These inspections are in addition to the Treatment, Storage, and Disposal (TSD) Unit inspections specified in Parts III and $V$ of the permit.

This inspection plan provides for the general inspection of the Hanford Facility. This plan does not provide for inspections:

- Inside buildings

- Monitoring equipment

- Safety and emergency equipment

- Security devices

- Operating and structural equipment that help prevent, detect, or respond to hazards

- Dangerous waste accumulation areas controlled under the requirements of Chapter 173-303-200 of the Washington Administrative Code (WAC) Dangerous Waste Regulations.

This $p l a n$ provides for scheduling of the inspections and defines general and specific items to be noted during the inspections.

\subsection{DEFINITIONS}

Responsible Organization (RO). The organization that has been determined to be responsible for an inspection finding that requires remedial action.

\subsection{REQUIREMENTS}

The portions of the 100, 200 East, 200 West, 300, 400, and 1100 Areas between TSD's will be inspected annually. The banks of the Columbia River contained within the Hanford Facility boundary will be inspected twice a year by boat. One inspection will be conducted during the Columbia River's low flow period; the other will be conducted during its high flow period. 
Inspections will be conducted in accordance with the provisions of WAC 173-303-320(2), except as noted in Section 2.0. The inspections wiTl be visual inspections of the areas and will follow the criteria outlined in Part II.0.1.C of the permit.

\subsection{RESPONSIBILITIES}

\subsection{RCRA Field Services}

Westinghouse Hanford Company's RCRA Field Services (RFS) group shall perform the following activities:

- Develop and maintain an annual inspection schedule to ensure that designated areas are inspected at the required frequency

- Notify the Washington State Department of Ecology (Ecology) of the inspection at least 7 days before the inspection

- Notify appropriate RO and/or environmental organizations of the inspection date

- Provide qualified personnel to conduct the inspections

- Compile a summary of individual area inspections

- Determine the RO for inspection findings requiring remedial action

- Provide a recommended course of action to the RO for deficiencies identified during the inspection that require remedial action

- Complete quarterly status reports and an annual inspection report

- Review all inspection documentation for environmental compliance and completeness before including them in the Hanford Facility Operating Record

- Compite all applicable inspection documentation into an inspection record for inclusion into the Hanford Facility Operating Record.

\subsection{RO}

When notified by RFS, RO shall perform the following tasks:

- Complete short term remedial actions

- Schedule long-term remedial actions with the schedule agreed to by Ecology, as required by Part II.0.2. of the permit

- Complete scheduled remedial actions 
WHC-EP-0850-1

- Submit copies of all documentation relating to the remedial actions to RFS for inclusion into the Hanford Facility Operating Record.

\subsection{PROCEDURE}

\subsection{INSPECTION CRITERIA}

The inspections will be visual inspections of the designated areas and river banks and will follow the criteria in Part II.0.1.c of the permit as described below.

\section{General Items}

Visually inspect for malfunctions, deteriorations, operator errors, and discharges that may cause or lead to the release of dangerous waste constituents to the environment or threaten human health.

\section{Specific Items}

- Remains of waste containers, labels or other waste management equipment

- Solid waste disposal sites not previously identified for remedial action

- Uncontrolled containers (e.g., orphan drums)

- Temporary or permanent activities that could generate an uncontrolled waste form

- Unpermitted waste discharges.

\subsection{FREQUENCY}

The portions of the 100, 200 East, 200 West, 300, 400, and 1100 Areas between TSDs and other buildings will be inspected once a year. The time scheduled for each area will be based on the size and complexity of the area.

The banks of the Columbia River, contained within the Hanford Facility boundary, will be inspected twice a year by boat. One inspection will be at the river's low flow period. The determination of low-water mark will be based on input from the Army Corps of Engineers Priest Rapids Dam Operations office. The low water flow period generally occurs in September or October. The time of the other river inspection is at the option of the Permitees. The option taken will be to inspect the river at the high water flow period, which generally occurs in the spring. This will allow for inspections of areas not accessible during the low-water period. Inspection schedules of the river may be affected by weather and/or river conditions that may present safety hazards. The general time frames for the inspection will be maintained. 


\subsection{INSPECTIONS}

Inspections will be conducted by a RFS inspector or inspectors who will determine the specific areas to be inspected and the method of inspection. The inspector will provide the materials for documenting the inspection and will ensure that all required document entries are made. The inspector will conduct a preinspection brief for all inspection participants. The brief will cover the scope of the inspection, safety, and any other concerns applicable to the inspection.

The inspection will be documented through the use of the Inspection Summary Cover Sheet (Attachment A), Inspection Summary Sheet (Attachment B) and a site plan map of the inspection area. At the completion of each inspection period the inspector will debrief the participants and record any additional concerns or findings. The inspector will formalize the Inspection Summary Sheet and recommend remedial actions. The summary sheet will then be submitted to the appropriate RO.

The following specific actions will be performed by RFS:

- Brief all participants on the scope of the inspection, safety, and any other concern applicable to the inspection

- Record the names of all participants and the date they participated on the inspection summary cover sheet

- Record a description of the area inspected

- Inspect the area in accordance with the inspection requirements outlined in Section 6.1 and record any findings (other observations may also be recorded)

- Mark the inspection map to indicate the areas that have been inspected, note the location of any findings

- Initiate actions that require an immediate response, such as an ongoing spill, and document the finding and corrective action

- Document findings from the inspection on the inspection summary sheet(s) and enter recommended course of remedial action

- Document a description of the area inspected on the inspection summary cover sheet

- Identify the RO and provide the RO with the formalize the inspection summary sheet(s) and recommended course of remedial action

- Retain all inspection documentation for inclusion into the annual inspection report. 
WHC-EP-0850-1

\subsection{REMEDIAL ACTIONS}

Remedial actions are the responsibility of the RO. Remedial actions are required for items meeting the criteria outlined in Section 6.1. RFS will provide the RO or with a recommended course of action for findings that require remedial action. The RO will schedule remedial actions and submit the schedule to Ecology. Remedial actions will be performed in accordance with the schedule agreed to by Ecology. The RO will notify RFS of remedial actions completed and submit supporting documentation. Actions will be recorded on the applicable inspection summary sheet or the supporting documentation filed for inclusion into the Hanford Facility Operating Record.

The following specific actions will be performed by the R0:

- Determine the required course of action

- Provide a schedule for completing remedial actions to RFS within 30 days for submission to Ecology for agreement

- Complete required actions on schedule

- Submit documentation of actions completed to RFS.

The following specific action will be performed by RFS:

- Review documentation submitted by the RO to ensure findings documented on the applicable inspection summary sheet have been corrected.

- File all applicable documentation for inclusion into the Hanford Facility Operating Record.

\subsection{INSPECTION REPORT}

The Hanford Facility RCRA Permit General Inspection will be documented with quarterly status reports and an annual inspection report prepared by RFS. The annual inspection report will replace the fourth quarter status report. The annual report will include an executive summary and a general overview of facility conditions and trends.

\subsection{RECORDS}

The Hanford Site General Inspection Record will include the inspection report, inspection schedules, the map used for the inspection, the inspection summary and cover sheets, and all documentation of remedial actions completed including schedules and supporting documents. Inspection records will meet the requirements of WAC-173-303-320(d) and will include at least the date, time of inspection, the printed name, the handwritten signature of the inspector, notation of all observations made, an account of spills or discharges, and the date and nature of any repairs or remedial actions taken. Inspection records will be kept in the Hanford Facility Operating Record 


\section{WHC-EP-0850-1}

either until 10 years after post-closure or until corrective action is complete and certified for the facility, whichever is later, as required by Part II.I.1. of the permit. 
WHC-EP-0850-1

ATTACHMENT A

HANFORD FACILITY RCRA PERMIT GENERAL INSPECTION SUMMARY COVER SHEET 
WHC-EP-0850-1

This page intentionally left blank. 
HANFORD FACILITY RCRA PERMIT GENERAL INSPECTION

Inspection Number:

Inspection Date:

Print Name

RFS Inspector:

Area Representative:

Department of Ecology Representative:

Department of Ecology Representative:

Other Inspection Participants:

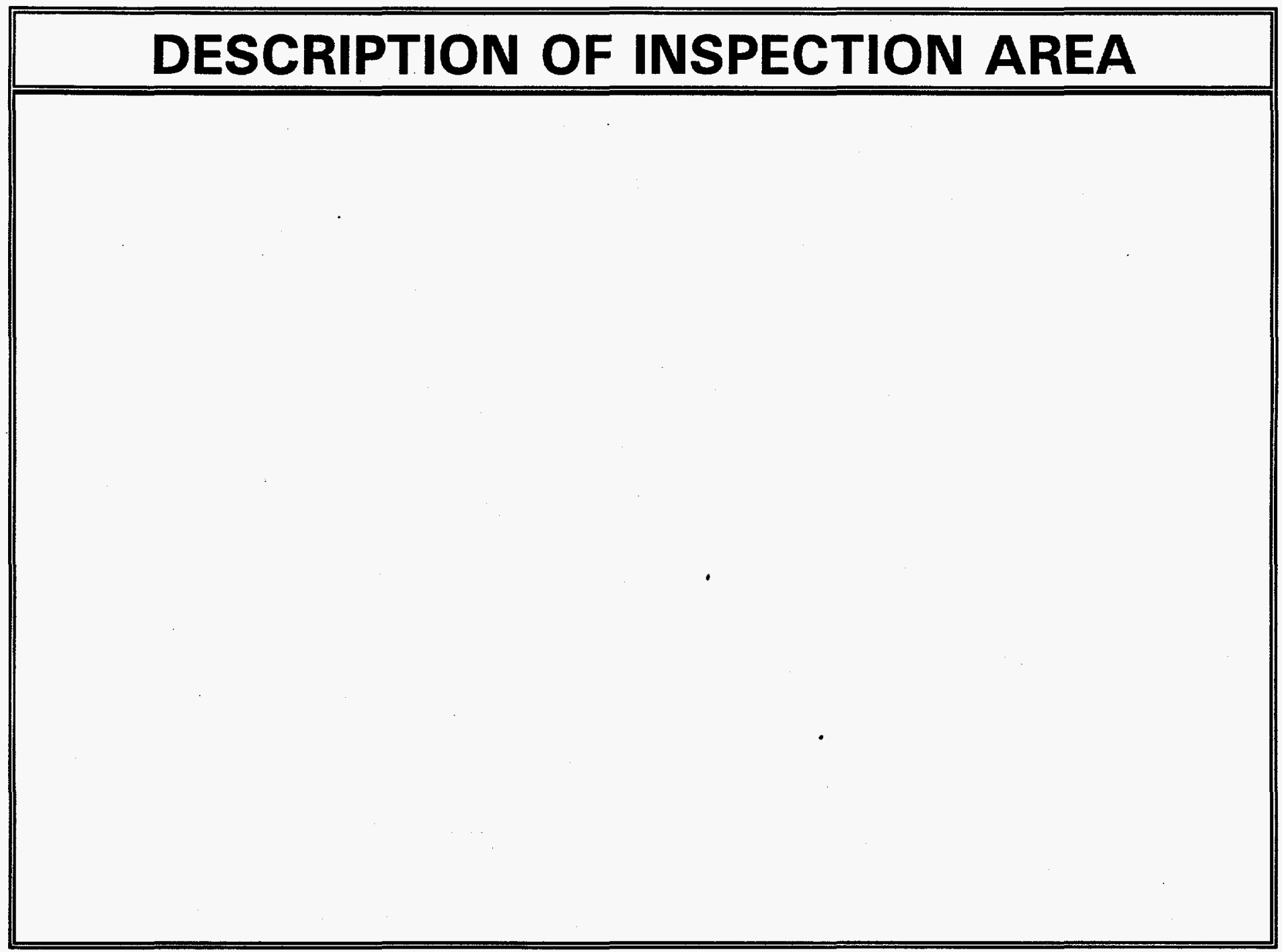


WHC-EP-0850-1

This page intentionally left blank. 
WHC-EP-0850-1

ATTACHMENT B

HANFORD FACILITY RCRA PERMIT GENERAL INSPECTION SUMMARY SHEET 
WHC-EP-0850-1

This page intentionally left blank. 
Inspection Number:

Page

of

HANFORD FACILITY RCRA PERMIT GENERAL INSPECTION SUMMARY SHEET

\begin{tabular}{|c|c|c|}
\hline $\begin{array}{l}\text { FINDINGS/OBSERVATIONS/ } \\
\text { RECOMMENDED REMEDIAL ACTION }\end{array}$ & REMEDIAL ACTION COMPLETED & $\begin{array}{l}\text { DATE } \\
\text { ACTION } \\
\text { COMPLETE }\end{array}$ \\
\hline $\begin{array}{l}\text { Item Number: } \\
\text { Action: } \\
\text { Responsible Organization: } \\
\text { Ran }\end{array}$ & & \\
\hline
\end{tabular}


WHC-EP-0850-1

This page intentionally left blank. 


\section{DISTRIBUTION}

Number of

Copies

ONSITE

2

U.S. Department of Energy, Richland Operations office

$$
\begin{array}{ll}
\text { C. E. Clark } & A 5-15 \\
\text { Public Reading } & \\
\text { Room } & A 1-65
\end{array}
$$

2

Bechtel Hanford, Inc.
R. L. Collins
H4-87
R. J. Landon
H4-86

2

\section{ICF Kaiser Hanford, Inc.}
B. J. Dixon
B4-20
C. A. Steward
B4-20

3 Pacific Northwest Laboratory
E. A. Flores
P7-79
B. A. Minton
P7-79
H. T. Tildon
P7-79

\section{Number of}

Copies

ONSITE

37

Westinghouse Hanford Company

D. Alison

D. B. Beagles (10)

$\mathrm{R} 1-52$

J. F. Brown

R. C. Brunke

H6-20

S. E. Campbel1

J. L. Demarest

D. J. Farquhar

D. L. Flyckt

C. J. Geier

E. M. Greager

M. J. Hall

D. E. Hare

S. E. Killoy

D. J. McBride

P. C. Miller

S. M. Price

D. E. Rasmussen

J. A. Remaize

R. W. Szelmeczka

S. A. Szendre

G. C. Triner

E. F. Votaw

D. J. Watson

Central Files

OSTI (2)
S5-03

H6-23

T4-05

G2-06

A1-05

S6-71

R2-36

H6-20

T6-14

N1-97

S6-70

T5-54

N2-33

H6-23

N $1-47$

L6-26

L4-96

H6-2O

T3-28

G2-02

X3-79

A3-88

E6-44 
WHC-EP-0850-1

This page intentionally left blank.

Distr-2 